\title{
IMPLEMENTASI PROGRAM GERAKAN LITERASI SEKOLAH PADA TAHAP PEMBIASAAN MEMBACA
}

\author{
Fidafatul Hidayati, Ma'as Shobirin, Fitria Martanti \\ Fakultas Agama Islam Universitas Wahid Hasyim Semarang \\ fidafatul151098@gmail.com
}

\begin{abstract}
Abstrak
Penelitian ini mengkaji tentang implementasi program gerakan literasi pada tahap pembiasaan membaca kelas IV di SDN Sampangan, mengkaji dampak dan peran guru dalam pelaksanaan program literasi. Penelitian ini merupakan penelitian lapangan (field research) dengan menggunakan pendekatan kualitatif. Teknik pengumpulan data dilakukan dengan menggunakan metode dokumentasi, observasi dan wawancara. Teknik analisis data dilakukan dengan cara reduksi data, penyajian data dan penarikan simpulan, sedangkan pengecekan keabsahan data dilakukan dengan ketekunan pengamatan, triangulasi teknik, dan triangulasi sumber. Simpulan penelitian menunjukkan bahwa Implementasi Program Gerakan Literasi pada Tahap Pembiasaan Membaca Kelas IV di SDN Sampangan 02 melalui enam tahap. Pertama memberikan waktu 10-15 menit untuk membaca. Pelaksanaan di dalam atau pun diluar kelas. Meresum apa yang telah dibaca dari buku bacaan tersebut. Menceritakan kembali apa yang telah dibaca di dedapan kelas secara suka rela. Memberikan apresiasi bagi peserta didik yang bercerita di depan kelas dan mencatat buku yang telah dibaca dan dipinjam oleh peserta didik di kartu baca. Adapun dampak positif adanya pembiasaan membaca yang dilaksanakan setiap hari membuat peserta didik menjadi semakin lebih gemar membaca dengan referensi bacaan yang lebih banyak. Peran guru kelas IV memiliki peranan yang sangat penting, salah satunya adalah guru sebagai pendamping dan fasilitator.
\end{abstract}

Kata Kunci: Implementasi, Program, Gerakan Literasi Sekolah, Pembiasaan Membaca

\begin{abstract}
This research study about implementation of literation movement program of reading habbit steps for 4th grader in SDN Sampangan, study about impact and teacher's role in conducting literation program. This research is field research with use qualitative approach. Technique of data collection is conducted by documentation, observation and interview. Technique of data analysis is done by data reduction, data presentation, and making conclusion while to check data validity is done by observation, triangulation technique and triangulation sources. The result show that The Implementation of Literation Movement Program on Reading Habituation Step for 4th Grader in SDN Sampangan 02 through six steps. First, giving time 10-15 minutes for reading. It can be conducted in class or out of class. Summerize what they are read from the textbook. Retelling what they are read in front of the class. Giving appreciate for student who are already retelling in front of the class and making a note for book which are already read and borrowed by the student in reading card. Positive impact of this activity is there are daily reading habbit which make students become keen on reading and improving their reading references. The role of 4 th grader teacher are as assistant and facilitator.
\end{abstract}

Keywords: implementation, program, Literation Movement Program, Reading Habituation 


\section{A. PENDAHULIAN}

Salah satu upaya proses pembelajaran dalam pendidikan adalah dengan kegiatan membaca. ${ }^{1}$ Membaca merupakan keterampilan berbahasa dan faktor yang paling penting dalam proses pembelajaran, karena dengan membaca peserta didik dapat memperoleh informasi yang telah dibacanya. Membaca merupakan salah satu kegiatan dalam berliterasi. Literasi tidak dapat dipisahkan dari dunia pendidikan. Literasi menjadi sarana peserta didik dalam mengenal, memahami, dan menerapkan ilmu yang didapatkannya di bangku sekolah.

Membaca pada hakikatnya adalah suatu yang rumit melibatkan banyak hal, tidak hanya sekedar melafalkan tulisan, tetapi juga melibatkan aktivitas visual, berpikir, psikolinguistik, dan metakognitif. Membaca sebagai proses visual merupakan proses menerjemahkan simbol tulis (huruf) ke dalam kata-kata lisan. Membaca sebagai suatu proses berpikir mencakup aktivitas pengenalan kata, pemahaman literal, interpretasi, membaca kritis, dan pemahaman kreatif. Pengenalan kata bisa berupa aktivitas membaca kata-kata dengan menggunakan kamus. ${ }^{2}$

Membaca merupakan kegiatan yang penting dalam kehidupan sehari-hari, karena membaca tidak hanya untuk memperoleh informasi, tetapi berfungsi sebagai alat untuk memperluas pengetahuan tentang banyak hal mengenai kehidupan. Membaca akan meningkatkan kemampuan memahami kata dan meningkatkan kemampuan berpikir, meningkatkan kreatifitas dan juga berkenalan dengan gagasan-gagasan baru. Membaca adalah sebuah kegiatan yang ringan dan sederhana karena dengan membaca akan memiliki banyak manfaat.

Menurut Endah Kusumawati menyebutkan manfaat membaca adalah sebagai berikut: ${ }^{3}$

a. Meningkatkan kadar intelektual.

b. Memperoleh berbagai pengetahuan hidup.

c. Memiliki cara pandang dan pola pikir yang luas.

d. Memperkaya perbendaharaan kata.

\footnotetext{
${ }^{1}$ Dalman, Keterampilan Membaca, Jakarta: rajawali Pers, 2013, hlm. 5.

${ }^{2}$ Farida Rahim, Pengajaran Membaca di Sekolah Dasar, Jakarta: Bumi Aksara, 2018, hlm. 2

3 Endah Kusumawati, Peningkatan Keterampilan Membaca Permulaan Melalui Pendekatan Pakem Siswa Kelas I Sd Jomblangan Banguntapan Bantul Tahun Ajaran 2011/2012 (Skripsi), Yogyakarta: Fakultas Ilmu Pendidikan UNY, 2012, hlm. 10-11.
} 
e. Mengetahui berbagai peristiwa yang terjadi di berbagai belahan dunia.

f. Meningkatkan keimanan.

g. Mendapatkan hiburan.

Membaca adalah salah satu dari empat keterampilan berbahasa yang disajikan dalam pembelajaran Bahasa Indonesia selain keterampilan menyimak, keterampilan berbicara, dan ketrampilan menulis. Hal ini sesuai dalam Undang-Undang No 20 Tahun 2003 tentang Sistim Pendidikan Nasional, bahwa membaca merupakan salah satu dari empat keterampilan pokok yang harus dibina dan dikembangkan dalam pendidikan bahasa. ${ }^{4}$ Untuk memahami berbagai hal tentang membaca, maka hal yang penting adalah memahami tahapan kegiatan membaca yang meliputi tahap prabaca, tahap saat membaca, dan tahap pasca baca.

a. Tahap prabaca

Tahap ini dimaksudkan untuk meningkatkan motivasi membaca dan mengaktifkan skemata yang dimiliki pembaca. Kegiatan pengaktifan skemata bertujuan untuk meningkatkan pemahaman pembaca terhadap materi bacaan dan membangun pengetahuan baru. Proses pemahaman akan terhambat jika skemata pembaca tidak disiapkan sebelumnya. Salah satu kegiatan yang termasuk dalam tahap ini adalah menentukan tujuan membaca, membuat daftar pertanyaan, dan sebagainya.

b. Tahap Saat Baca

Tahap ini adalah tahap utama dalam membaca. Pada tahap ini, seseorang mengerahkan kemampuannya untuk mengolah bacaan menjadi bacaan yang bermanfaat. Salah satu kegiatan yang termasuk dalam tahap ini adalah membaca dengan teliti bacaan atau buku, membuat analisis dan kesimpulan secara kritis, dan sebagainya.

c. Tahap Pascabaca

Tahap ini adalah tahap terakhir dari kegiatan membaca. Di tahap ini, seseorang melakukan suatu perbuatan atau mengubah sikap mental karena "dorongan" hasil membaca. Salah satu kegiatan yang termasuk dalam tahap ini adalah menentukan sikap seperti menerima atau menolak gagasan/isi bacaan. ${ }^{5}$

\footnotetext{
${ }^{4}$ Irdawati, Yunidar, dan Darmawan, Meningkatkan Kemampuan Membaca Permulaan dengan Menggunakan Media Gambar Kelas I di MIN Buol, Jurnal Kreatif Tadulako Online, Tadulako: FKIP Universitas Tadulako, Volume 5 (4), hlm. 4.

${ }^{5}$ Nurhadi, Teknik Membaca, Jakarta: Bumi Aksara, 2016, hlm. 4-5 .
} 
Menurut Yulisa Wandasari kemampuan membaca siswa Indonesia masih tergolong rendah. ${ }^{6}$ Terbukti dari hasil penelitian yang dilakukan oleh Programme for International Student Assesment ( PISA) pada tahun 2012 menempatkan Indonesia pada peringkat ke-64 dari 65 negara peserta dengan skor 396 (skor rata-rata adalah 496). ${ }^{7}$ Hasil penelitian pada tahun 2015 menunjukkan peserta didik Indonesia berada pada peringkat ke-61 dari 70 negara yang ikut serta berpartisipasi dalam PISA. Indonesia memperoleh skor 397 (skor rata-rata OECD 493).

Berdasarkan data yang diperoleh dari penelitian tahun 2015, posisi Indonesia di bawah Vietnam yang menempati urutan ke- 8 dan Thailand yang menempati urutan ke54. Sehingga menjadi persoalan yang cukup serius bagi bangsa Indonesia dalam hal membaca khususnya, karena membaca merupakan dasar untuk memperoleh pengetahuan, keterampilan, dan pembentukan sikap peserta didik. Menurut Ma'as Shobirin dan Peni Susapti, salah seorang pustakawan Republik Indonesia Perpustakaan Indonesia (RI), menjelaskan bahwa pada tahun 2016 minat baca warga negara Indonesia berada di peringkat ke-60 dari 61 negara. ${ }^{8}$ Berdasarkan studi "Most Littered Nation In the World" yang dilakukan oleh Central Connecticut State University pada Maret 2016 lalu, menjelaskan bahwa Indonesia menduduki peringkat ke-60 dari 61 negara dalam hal minat membaca. ${ }^{9}$

Ada beberapa pihak yang semestinya terlibat dalam peningkatan minat baca, yakni pemerintah, perpustakaan, pustakawan dan masyarakat. Perpustakaan dalam hal ini menjadi titik sentral yang paling mendominasi dalam upaya peningkatan minat baca. Hal ini dikarenakan secara umum masyarakat kita, belum memprioritaskan belanja buku dalam agenda keluarga, sehingga ketika minat baca mulai muncul, perpustakaanlah yang menjadi tempat menyalurkannya. Belum banyak keluarga yang

6 Yulisa Wandasari, Implementasi Gerakan Literasi Sekolah (GLS) Sebagai Pembentuk Pendidikan Berkarakter, Jurnal Manajemen, Kepemimpinan, dan Supervisi Pendidikan (JMKSP), Sumatra Selatan: SMKN 1 Tanah Abang, Volume 1 (1), 2017, hlm. 329.

7 Suyono, (at,all.), Implementasi Gerakan Literasi Sekolah Pada Pembelajaran Tematik Di Sekolah Dasar, Jurnal Sekolah Dasar Kajian Teori dan Praktek Pendidikan, Malang: Universitas Negeri Malang, Nomor 2, 2017, hlm. 117.

${ }^{8}$ Ma'as Sobirin dan Peni Susapti, Cultural literacy building of primary school students as basic concept, Muddarrisa: Jurnal Kajian Pendidikan Islam, Salatiga: IAIN Salatiga, Volume 10 (2), 2018, hlm. 207.

${ }^{9}$ Eruin Endaryanta, Implementasi Program Gerakan Literasi Sekolah Di SD Kristen Kalam Kudusdan Sd Muhammadiyah Suronatan, Jurnal Kebijakan Pendidikan, Yogyakarta: Fakultas Ilmu Pendidikan UNY, Volume 6 (7), 2017, hlm. 733 
memiliki semacam perpustakaan kecil tempat koleksi buku yang menyediakan informasi bagi anggota keluarganya. Padahal jika ada, hal ini bisa memacu meningkatnya minat baca dan dapat dilakukan sejak dini. Oleh karena itu perpustakaan memegang kunci penting dalam meningkatkan minat baca. ${ }^{10}$

Untuk itu demi tercapainya peningkatan minat baca yang tinggi, baru-baru ini Kementerian Pendidikan dan Kebudayaan (Kemendikbud) memperkuat pendidikan karakter dengan dibentuknya sebuah Gerakan Literasi. Program ini tertuang dalam Permendikbud RI Nomor 23 Tahun 2015 Tentang Penumbuhan Budi Pekerti. Gerakan literasi merupakan gerakan sosial yang melibatkan seluruh pemangku kepentingan, sekolah, masyarakat, dunia usaha (penerbit dan media massa). Menurut Hamdan Hussein dkk gerakan ini bertujuan untuk menumbuhkembangkan budaya literasi membaca dan menulis, meningkatkan kompetensi literasi, dan menjadikan sekolah sebagai taman belajar yang menyenangkan dan ramah anak. ${ }^{11}$ Pelibatan unsur eksternal dan unsur publik, yakni pada orang tua peserta didik, alumni, masyarakat, dunia usaha dan industri juga menjadi komponen penting dalam gerakan literasi sekolah. ${ }^{12}$

Menurut Hamdan Hussein dkk Gerakan literasi yang mencakup sekolah, keluarga, dan masyarakat diawali dengan penumbuhan minat baca. Tingkat minat baca masyarakat di Indonesia sangat rendah. Sumber daya manusia yang ada dikerahkan untuk melakukan kampanye minat baca dengan menggandeng pegiat literasi, sehingga dapat menampung partisipasi publik. Kegagalan gerakan penumbuhan minat baca di masyarakat selama ini, merupakan dampak akibat penggunaan pendekatan struktural, bukan fungsional. Misalnya, perpustakaan daerah dibuka pada pagi hari dan ditutup sore hari mengikuti jam kerja Pegawai Negeri Sipil (PNS). Semestinya pegiat taman bacaan masyarakat yang telah teruji komitmennya dalam penyelenggaraan kegiatan literasi dilibatkan dalam pengelolaan perpustakaan. Maka dengan begitu suasana perpustakaan akan lebih hidup. Perpustakaan tak lagi sekedar tempat membaca dan meminjam buku. Lebih dari itu, ia menjadi pusat belajar dan interaksi masyarakat yang

10 Aliyatin Nafisah, Arti Penting Perpustakaan Bagi Upaya Peningkatan Minat Baca Masyarakat, Jurnal Pustakaan Libraria, STAIN Kudus, Volume 2 (2), 2017, hlm. 70.

${ }^{11}$ Hamdan Husein Batubara, Dessy Noor Ariani, Implementasi Program Gerakan Literasi di Sekolah Dasar Negeri Gugus Sungai MIAI Banjarmasin, Jurnal Pendidikan Sekolah Dasar JPSD Universitas Islam Kalimantan MAB Banjarmasin, Volume 4 (1), 2018, hlm. 17

${ }^{12}$ T.p., Panduan Gerakan Literasi Sekolah Dasar, Jakarta: Direktorat Jenderal Pendidikan Dasar dan Menengah Kementerian Pendidikan dan Kebudayaan 2016, hlm. 1. 
ingin maju melalui beragam kegiatan literasi, diantaranya bedah buku, diskusi tentang buku, dan festival. ${ }^{13}$

Salah satu lembaga formal pendidikan dasar di Semarang yang sudah mengimplementasikan Gerakan Literasi Sekolah di atas adalah Sekolah Dasar Negeri Sampangan 02. Sekolah Dasar Negeri Sampangan 02 adalah sebuah lembaga sekolah yang memiliki banyak prestasi. Sekolah ini juga memperoleh beberapa predikat seperti sekolah Penguatan Pendidikan Karakter (PPK), Sekolah Pendidikan Keluarga dan masih banyak lagi prestasi yang telah diraih oleh sekolah tersebut. Peserta didik di sekolah ini juga memiliki tingkat literasi yang rendah. Salah satunya adalah pada kelas IV yang memiliki kurangnya minat baca yang cukup banyak bagi peserta didik yang ada di SD Negeri Sampangan 02. Rendahnya minat baca membuat pihak kepala sekolah dan sejajarnya sepakat untuk menerapkan gerakan literasi ini. Berdasarkan latar belakang tersebut peneliti tertarik untuk melakukan penelitian yang berkaitan dengan pelaksanaan program Gerakan Literasi Sekolah tahap pembiasaan membaca di Sekolah Dasar Negeri Sampangan 02 sehingga dapat menjadi referensi dan inspirasi bagi sekolah lain di Semarang khususnya dan Indonesia pada umumnya.

\section{B. METODE PENELITIAN}

Penelitian ini merupakan penelitian lapangan atau field Research dengan menggunakan pendekatan kualitatif. Penelitian lapangan yaitu yang dilakukan di kancah atau tempat terjadinya gejala-gejala. ${ }^{14}$

Penelitian berupaya untuk mendiskipsikan dan menganalisis program gerakan literasi sekolah. Fokus pada kajian ini diantaranya adalah implementasi program gerakan literasi pada tahap pembiasaan membaca kelas IV di Sekolah Dasar Negeri Sampangan 02, dampak yang terjadi dalam pelaksanaan program gerakan literasi pada tahap pembiasaan membaca kelas IV di Sekolah Dasar Negeri Sampangan 02, peran guru dalam pelaksanaan program gerakan literasi pada tahap pembiasaan membaca kelas IV di Sekolah Dasar Negeri Sampangan 02.

${ }^{13}$ Hamdan Husein Batubara, Dessy Noor Ariani, Implementasi Program Gerakan Literasi di Sekolah Dasar Negeri Gugus Sungai MIAI Banjarmasin, Jurnal Pendidikan Sekolah Dasar JPSD Universitas Islam Kalimantan MAB Banjarmasin, Volume 4 (1), 2018, hlm. 17

${ }^{14}$ M. Iqbal Hasan, Pokok-pokok Materi Metodologi Penelitian dan Aplikasinya, Jakarta: Ghalia Indonesia, 2002, hlm. 11. 
Sumber data yang digunakan pada penelitian ini ada dua, pertama sumber data primer dan kedua sumber data sekunder. Metode pengumpulan data yang digunakan ada tiga, pertama, metode wawancara, dokumentasi dan observasi. Metode Wawancara adalah percakapan dengan maksud tertentu. Percakapan ini dilakukan oleh dua pihak, yaitu pewawancara yang mengajukan pertanyaan dan terwawancara yang memberikan jawaban atas pertanyaan. Peneliti menggunakan wawancara dalam menggali keterangan dari subyek penelitian. Keterangan yang ingin digali seperti persepsi, pemahaman, pendapat terkait pelaksanaan atau implementasi program Gerakan Literasi Sekolah pada tahap pembiasaan membaca kelas IV. Peneliti mewawancarai kepala sekolah guna memperoleh informasi tentang kebijakan sekolah dalam mengimplementasikan program Gerakan Literasi Sekolah. Peneliti juga mewawancarai wali kelas, petugas perpustakaan dan peserta didik untuk menggali informasi tentang teknis pelaksanaan program Gerakan Literasi Sekolah sedangkan keterangan yang ingin digali dari wali murid adalah tentang keterlibatan mereka dalam implementasi program Gerakan Literasi Sekolah pada tahap pembiasaan membaca kelas IV tersebut.

Adapun metode observasi adalah metode metode pengumpulan data dengan cara observasi langsung terhadap obyek penelitian. Observasi atau pengamatan digunakan dalam rangka mengumpulkan data dalam suatu penelitian, merupakan hasil perbuatan jiwa secara aktif dan penuh perhatian untuk menyadari adanya suatu rangsangan tertentu yang diinginkan, atau suatu studi yang disengaja atau sistematis tentang keadaan/fenomena sosial dan gejal-gejala psikis dengan jalan mengamati dan mencatat. ${ }^{15}$

Adapun jenis metode observasi yang yang peneliti gunakan adalah non partisipan, dimana peneliti tidak ambil bagian dalam kehidupan subyek yang diobservasi. Metode ini digunakan untuk memperoleh data tentang implementasi program gerakan literasi pada tahap pembiasaan membaca kelas IV di Sekolah Dasar Negeri Sampangan 02.

Metode dokumentasi metode untuk menggali data penelitian dari berbagai dokumen maupun laporan. Hal ini karena dokumentasi berasal dari kata dokumen, yaitu barang-barang tertulis. Dokumentasi adalah metode yang digunakan untuk mencari data-data yang mengenai hal-hal atau variabel yang berupa catatan, transkip,

\footnotetext{
${ }^{15}$ Mardalis, Metode Penelitian, Jakarta: Bumi Aksara, 2002, hlm. 63
} 
buku, surat kabar, majalah dan sebagainya ${ }^{16}$. Metode dokumentasi ini sebagai pelengkap dari metode wawancara maupun observasi yang dilakukan.

Setelah data penelitian diperoleh secara lengkap maka langkah selanjutnya yaitu menganalisis data. Metode analisis data yang digunakan dalam penelitian ini adalah analisis data kualitatif, mengikuti konsep yang diberikan Miles and Huberman, yaitu data reduction, data display, conclussion drawing/verification.

\section{HASIL DAN PEMBAHASAN}

Program gerakan literasi sekolah merupakan salah satu dari program yang dibuat oleh kemendikbud. Tujuan Kemendikbud membuat program ini adalah untuk meningkatkan minat baca penduduk di Indonesia yang salah satunya disosialisasikan untuk sekolah yang ada di Indonesia. Sudah banyak sekolah yang telah mengimplementasikan program ini, terutama dengan tujuan untuk meningkatkan minat baca siswa-siswa di berbagai sekolah di Indonesia termasuk di SD Negeri Sampangan 02. Mengingat pentingnya minat baca, perlu adanya pelaksanaan sebagai bentuk realisasi dari adanya program, kegiatan rutin maupun pembiasaan yang sudah ditetapkan di sekolah. Penerapan program-program, kegiatan rutin maupun pembiasaan tersebut diterapkan dalam aktifitas sehari-hari di sekolah dengan melibatkan semua guru terutama guru kelas sebagai sosok yang bertanggung jawab sebagai orang tua peserta didik di sekolah yang memberikan pengetahuan dan pembinaan karakter kepada peserta didik. Dukungan dari pihak di luar sekolah seperti orang tua peserta didik, warga masyarakat, dan lingkungan juga sangat dibutuhkan untuk ikut serta membangun minat baca peserta didik dengan ikut serta mengontrol peserta didik dalam membaca buku sebagai bentuk kepedulian terhadap pentingnya minat baca peserta didik.

Literasi dalam bahasa Inggris berarti literacy yang berasal dari bahasa Latin littera (huruf) yang artinya melibatkan penguasaan sistem-sistem tulisan dan konvensikonvensi yang menyertainya. Secara umum, literasi dapat diartikan sebagai keberaksaraan, yaitu kemampuan seseorang membaca dan menulis. ${ }^{17}$ Namun demikian, literasi utamanya berhubungan dengan bahasa dan bagaimana bahasa itu digunakan. Adapun sistem bahasa tulis itu sifatnya sekunder. Manakala berbicara

\footnotetext{
${ }^{16}$ Suharsimi Arikunto, Prosedur Penelitian Kualitatif, Jakarta: Rineka Cipta, 2010, hlm. 274

17 T.p, Pedoman Pelaksanaan Gerakan Nasional Literasi Bangsa, Jakarta: Bidang Pembelajara Pusat Pembinaan dan Pembinaan Bahasa Kementerian Pendidikan dan Kebudayaan, 2016, hlm. 8.
} 
mengenai bahasa, tentunya tidak lepas dari pembicaraan mengenai budaya karena bahasa itu sendiri merupakan bagian dari budaya. Pendefinisian istilah literasi tentunya harus mencakup unsur yang melingkupi bahasa itu sendiri, yakni situasi sosial budayanya. ${ }^{18}$ Peneliti melakukan pengumpulan data dari catatan terkait tentang digunakan untuk mengumpulkan data-data yang berkaitan dengan implementasi program gerakan literasi pada tahap pembiasaan membaca kelas IV di Sekolah Dasar Negeri Sampangan 02 di dalam metode ini, selain itu juga dokumen-dokumen lain yang berkaitan dengan program gerakan literasi pada tahap pembiasaan membaca serta mengenai profil Sekolah Dasar Negeri Sampangan 02 yang menjadi lokasi penelitian.

Literasi Sekolah dalam konteks Gerakan Literasi Sekolah adalah kemampuan mengakses, memahami, dan menggunakan sesuatu secara cerdas melalui berbagai aktivitas, antara lain membaca, melihat, menyimak, menulis, dan/atau berbicara. ${ }^{19}$ Menurut buku panduan gerakan literasi nasional, Gerakan Literasi Sekolah (GLS) merupakan gerakan literasi yang aktivitasnya banyak dilakukan di sekolah dengan melibatkan siswa, pendidikan dan tenaga kependidikan, serta orang tua. GLS dilakukan dengan menampilkan praktik baik tentang literasi dan menjadikannya sebagai kebiasaan serta budaya di lingkungan sekolah. Literasi juga dapat diintegrasikan dalam kegiatan belajar mengajar di sekolah sehingga menjadi bagian tidak terpisahkan dari semua rangkaian kegiatan siswa dan pendidik, baik di dalam maupun di luar kelas Pendidik dan tenaga kependidikan tentu memiliki kewajiban moral sebagai teladan dalam hal berliterasi. Agar lebih masif, program GLS melibatkan partisipasi publik, seperti pegiat literasi, orang tua, tokoh masyarakat, dan profesional. Gerakan Literasi Sekolah dikembangkan berdasarkan sembilan agenda prioritas (Nawacita) yang terkait dengan tugas dan fungsi Kemendikbud, khususnya Nawacita nomor 5, 6, 8, dan 9. Butir Nawacita yang dimaksudkan adalah (5) meningkatkan kualitas hidup manusia dan masyarakat Indonesia; (6) meningkatkan produktivitas rakyat dan daya saing di pasar internasional sehingga bangsa Indonesia bisa maju dan bangkit bersama bangsa-bangsa Asia lainnya; (8) melakukan revolusi karakter bangsa; (9) memperteguh kebinekaan dan memperkuat restorasi sosial Indonesia. Empat butir

\footnotetext{
${ }^{18}$ Shinta Tri Septiani. Analisis Literasi Media Pegawai Perpustakaan Proklamator Bung Hatta Bukittinggi (Skripsi). Sumatra Utara: Fakultas Ilmu Budaya Universitas Sumatera Utara, 2014, hlm. 5.

19 Indah Wijaya Antasari, Implementasi Gerakan Literasi Sekolah Tahap Pembiasaan di MI Muhammadiyah Gandatapa Sumbang Banyumas, JURNAL LIBRIA, Purwokerto: IAIN Purwokerto, Volume 9 (1), 2017, hlm. 14-15.
} 
Nawacita tersebut berkaitan erat dengan komponen literasi sebagai modal pembentukan sumber daya manusia yang berkualitas, produktif dan berdaya saing, berkarakter, serta nasionalis. $^{20}$

Keberhasilan berliterasi di sekolah perlu diupayakan melalui kegiatan-kegiatan yang menumbuhkan budaya literasi. Kegiatan-kegiatan tersebut mengacu pada lima aspek strategi yang sudah ditetapkan. Aspek-aspek tersebut diantaranya:

a. penguatan Kapasitas Fasilitator

1) Pelatihan guru dan tenaga kependidikan dalam menerapkan literasi pada pembelajaran;

2) Pelatihan guru dan tenaga kependidikan dalam pembuatan mainan edukatif berbasis literasi; dan

3) Forum diskusi bagi warga sekolah untuk mengembangkan kegiatan literasi dan menigkatkan kemampuan berliterasi.

b. Penigkatan Jumlah dan Ragam Sumber Bacaan Bermutu

1) Penyediaan bahan bacaan nonpelajaran yang beragam;

2) Penyediaan alat peraga dan mainan edukatif yang mendukung kegiatan literasi;

3) Penyediaan bahan belajar literasi dalam bentuk digital; dan

4) Program menulis buku bagi siswa, guru, dan tenaga kependidikan.

c. Perluasan Akses terhadap Sumber Belajar dan Cakupan Peserta Belajar

1) Pengembangan sarana penunjang yang membentuk ekosistem kaya literasi;

2) Penyediaan laboratorium yang berkaitan dengan literasi, misalnya, laboratorium bahasa, sains, finansial, dan digital;

3) Penyediaan pojok baca, baik di tiap kelas maupun di tempat-tempat strategis di sekolah;

4) Pengoptimalan perpustakaan sekolah;

5) Penyelenggaraan open house oleh sekolah yang sudah mengembangkan literasi;

6) Program pengimbasan sekolah; dan

7) Pelaksanaan kampanye literasi.

${ }^{20}$ T.p., Panduan Gerakan Literasi Sekolah Dasar, Jakarta: Direktorat Jenderal Pendidikan Dasar dan Menengah Kementerian Pendidikan dan Kebudayaan 2016, hlm. 1-2 
d. Peningkatan Pelibatan Publik

1) Pelaksanaan sesi diskusi dengan tokoh atau pegiat berbagai bidang literasi mengenai pengalaman dan pengetahuan mereka terkait dengan bidang yang mereka kuasai;

2) Pelaksanaan festival atau bulan literasi yang melibatkan pakar, pegiat literasi, dan masyarakat umum; dan

3) Pelibatan Badan Usaha Miliki Negara (BUMN) dan Dunia Usaha dan Dunia Industri (DUDI) dalam pengadaan bahan bacaan dan kegiatan literasi di sekolah.

e. Penguatan Tata Kelola

1) Pengalokasian waktu atau jadwal khusus untuk melakukan berbagai kegiatan literasi di sekolah;

2) Pengalokasian anggaran untuk mendukung literasi di sekolah;

3) Pembentukan tim literasi sekolah yang terdiri atas kepala sekolah, pengawas, guru, dan wakil orang tua peserta didik dengan tugas memantau berjalannya kegiatan-kegiatan literasi di sekolah;

4) Pembuatan kebijakan yang mengatur kegiatan literasi di sekolah sehingga dapat memaksimalkan keterlibatan semua warga sekolah; dan

5) Penguatan peran komite sekolah untuk membangun relasi kerja sama dan komitmen dalam melaksanakan kegiatan literasi.

sama dan komitmen dalam melaksanakan kegiatan literasi.

Target Pencapaian Pelaksanaan Gerakan Literasi Sekolah di Sekolah Dasar dapat menciptakan ekosistem pendidikan di Sekolah Dasar yang literat. Ekosistem pendidikan yang literat adalah lingkungan yang:

a. menyenangkan dan ramah peserta didik, sehingga menumbuhkan semangat warganya dalam belajar;

b. semua warganya menunjukkan empati, peduli, dan menghargai sesama;

c. menumbuhkan semangat ingin tahu dan cinta pengetahuan;

d. memampukan warganya cakap berkomunikasi dan dapat berkontribusi kepada lingkungan sosialnya; dan 
e. mengakomodasi partisipasi seluruh warga sekolah dan lingkungan eksternal Sekolah Dasar. $^{21}$

Kegiatan literasi di tahap pembiasaan meliputi dua jenis kegiatan membaca untuk kesenangan, yakni membaca dalam hati dan membacakan nyaring oleh guru. Secara umum, kedua kegiatan membaca memiliki tujuan, antara lain: meningkatkan rasa cinta baca di luar jam pelajaran, meningkatkan kemampuan memahami bacaan, meningkatkan rasa percaya diri sebagai pembaca yang baik dan menumbuhkembangkan penggunaan berbagai sumber bacaan.

Kedua kegiatan membaca ini didukung oleh penumbuhan iklim literasi sekolah yang baik. Pada tahap pembiasaan, iklim literasi sekolah diarahkan pada pengadaan dan pengembangan lingkungan fisik, seperti: buku-buku nonpelajaran (novel, kumpulan cerpen, majalah, komik, dsb), sudut baca kelas untuk tempat koleksi bahan bacaan dan poster-poster tentang motivasi pentingnya membaca.

Pada prinsipnya gerakan literasi sekolah harus memenuhi prinsip utama dalam pelaksananya, yang meliputi:

a. Perkembangan literasi berjalan sesuai tahap perkembangan yang dapat diprediksi. Tahap perkembangan anak dalam belajar membaca dan menulis saling beririsan antartahap perkembangan. Memahami tahap perkembangan literasi peserta didik dapat membantu sekolah untuk memilih strategi pembiasaan dan pembelajaran literasi yang tepat sesuai kebutuhan perkembangan mereka.

b. Program literasi yang baik bersifat berimbang Sekolah yang menerapkan program literasi berimbang menyadari bahwa tiap peserta didik memiliki kebutuhan yang berbeda. Oleh karena itu, strategi membaca dan jenis teks yang dibaca perlu divariasikan dan disesuaikan dengan jenjang pendidikan. Program literasi yang bermakna dapat dilakukan dengan memanfaatkan bahan bacaan kaya ragam teks, seperti karya sastra untuk anak dan remaja.

c. Program literasi terintegrasi dengan kurikulum Pembiasaan dan pembelajaran literasi di sekolah adalah tanggung jawab semua guru di semua mata pelajaran sebab pembelajaran mata pelajaran apapun membutuhkan bahasa, terutama membaca dan

21 T.p, Panduan Gerakan Literasi Sekolah di Sekolah Dasar, Jakarta: Direktorat Pembinaan Sekolah Dasar Direktorat Jenderal Pendidikan Dasar dan Menengah Kementerian Pendidikan dan Kebudayaan , 2016, hlm. 3 
menulis. Dengan demikian, pengembangan profesional guru dalam hal literasi perlu diberikan kepada guru semua mata pelajaran.

d. Kegiatan membaca dan menulis dilakukan kapanpun Misalnya, 'menulis surat kepada presiden' atau 'membaca untuk ibu' merupakan contoh-contoh kegiatan literasi yang bermakna.

e. Kegiatan literasi mengembangkan budaya lisan Kelas berbasis literasi yang kuat diharapkan memunculkan berbagai kegiatan lisan berupa diskusi tentang buku selama pembelajaran di kelas. Kegiatan diskusi ini juga perlu membuka kemungkinan untuk perbedaan pendapat agar kemampuan berpikir kritis dapat diasah. Peserta didik perlu belajar untuk menyampaikan perasaan dan pendapatnya, saling mendengarkan, dan menghormati perbedaan pandangan.

f. Kegiatan literasi perlu mengembangkan kesadaran terhadap keberagaman Warga sekolah perlu menghargai perbedaan melalui kegiatan literasi di sekolah. Bahan bacaan untuk peserta didik perlu merefleksikan kekayaan budaya Indonesia agar mereka dapat terpajan pada pengalaman multikultural.

Pada dasarnya tahapan gerakan literasi sekolah dalam pelaksanaannya Menurut Direktorat Jenderal Pendidikan Dasar dan Menengah adalah sebagai berikut: ${ }^{22}$

1. Tahap ke-1 Pembiasaan kegiatan membaca yang menyenangkan di bacaan dan terhadap kegiatan membaca dalam diri warga sekolah. Penumbuhan minat baca merupakan hal fundamental bagi pengembangan kemampuan literasi siswa.

2. Tahap ke-2 Pengembangan minat baca untuk meningkatkan kemampuan literasi. Kegiatan literasi pada tahap ini bertujuan mengembangkan kemampuan memahami bacaan dan mengaitkannya dengan pengalaman pribadi, berpikir kritis, dan mengolah kemampuan komunikasi secara kreatif melalui kegiatan menanggapi bacaan.

3. Tahap ke-3 Pembelajaran berbasis literasi. Kegiatan literasi pada tahap pembelajaran bertujuan mengembangkan kemampuan memahami teks dan mengaitkannya dengan pengalaman pribadi, berpikir kritis, dan mengolah kemampuan komunikasi secara kreatif melalui kegiatan menanggapi teks buku bacaan pengayaan dan buku hlm. 10-11

${ }^{22}$ Imelda Aprilia, Pelaksanaan Program Gerakan Literasi, Purwokerto: FKIP PGSD UMP, 2017, 
pelajaran. Tahap ini ada tagihan yang sifatnya akademis (terkait dengan mata pelajaran)

Sasaran untuk gerakan literasi sekolah mencakup beberapa orang atau instanti yang utama, yaitu sebagai berikut:

1. Sekolah Dasar/MI

2. Perpustakaan/TBM

3. Pemerintah

4. Umum (swasta, LSM, dan perorangan). ${ }^{23}$

Untuk memahami kegiatan literasi hal yang terpenting adalah memahami komponenkomponen literasi sebagai berikut:

a. Literasi Dini (Early Literacy), yaitu kemampuan untuk menyimak, memahami bahasa lisan, dan berkomunikasi melalui gambar dan lisan yang dibentuk oleh pengalamannya berinteraksi dengan lingkungan sosialnya di rumah. Pengalaman peserta didik dalam berkomunikasi dengan bahasa ibu menjadi fondasi perkembangan literasi dasar.

b. Literasi Dasar (Basic Literacy), yaitu kemampuan untuk mendengarkan, berbicara, membaca, menulis, dan menghitung (counting) berkaitan dengan kemampuan analisis untuk memperhitungkan (calculating), mempersepsikan informasi (perceiving), mengomunikasikan, serta menggambarkan informasi (drawing) berdasarkan pemahaman dan pengambilan kesimpulan pribadi.

c. Literasi Perpustakaan (Library Literacy), antara lain, memberikan pemahaman cara membedakan bacaan fiksi dan nonfiksi, memanfaatkan koleksi referensi dan periodikal, memahami Dewey Decimal System sebagai klasifikasi pengetahuan yang memudahkan dalam menggunakan perpustakaan, memahami penggunaan katalog dan pengindeksan, hingga memiliki pengetahuan dalam memahami informasi ketika sedang menyelesaikan sebuah tulisan, penelitian, pekerjaan, atau mengatasi masalah.

d. Literasi Media (Media Literacy), yaitu kemampuan untuk mengetahui berbagai bentuk media yang berbeda, seperti media cetak, media elektronik (media radio,

${ }^{23}$ Mulyo Teguh, Aktualisasi Kurikulum 2013 Di Sekolah Dasar Melalui Gerakan Literasi Sekolah Untuk Menyiapkan Generasi Unggul Dan Berbudi Pekerti, Pengawas pada Dinas Pendidikan Kabupaten Pati, Prosiding Seminar Nasional, 2017, hlm. 21. 
media televisi), media digital (media internet), dan memahami tujuan penggunaannya.

e. Literasi Teknologi (Technology Literacy), yaitu kemampuan memahami kelengkapan yang mengikuti teknologi seperti peranti keras (hardware), peranti lunak (software), serta etika dan etiket dalam memanfaatkan teknologi.

f. Literasi Visual (Visual Literacy), adalah pemahaman tingkat lanjut antara literasi media dan literasi teknologi, yang mengembangkan kemampuan dan kebutuhan belajar dengan memanfaatkan materi visual dan audiovisual secara kritis dan bermartabat. Tafsir terhadap materi visual yang tidak terbendung, baik dalam bentuk cetak, auditori, maupun digital (perpaduan ketiganya disebut teks multimodal), perlu dikelola dengan baik. Bagaimanapun di dalamnya banyak manipulasi dan hiburan yang benarbenar perlu disaring berdasarkan etika dan kepatutan. ${ }^{24}$

Pembiasaan kegiatan membaca yang menyenangkan di ekosistem sekolah merupakan hal yang cukup penting. Pembiasaan ini bertujuan untuk menumbuhkan minat terhadap bacaan dan terhadap kegiatan membaca dalam diri warga sekolah. Penumbuhan minat baca merupakan suatu hal yang fundamental bagi pengembangan kemampuan literasi peserta didik. ${ }^{25}$ Adapun kegiatan di dalam tahap pembiasaan ini yaitu 15 menit membaca setiap hari sebelum jam pelajaran melalui kegiatan membaca buku secara nyaring; membangun lingkungan fisik sekolah yang kaya literasi.

Tahapan ini, sekolah menyediakan berbagai buku dan bahan bacaan yang dapat menarik minat peserta didik dan melaksanakan kegiatan yang meningkatkan minat baca peserta didik. Misalnya, menata sarana dan area baca, menciptakan lingkungan yang kaya teks, mendisiplinkan kegiatan membaca 15 menit sebelum pelajaran dimulai, melibatkan publik dalam gerakan literasi sekolah. ${ }^{26}$

Kegiatan 15 menit membaca ditahap pembiasaan, guru tidak perlu bertanya apapun tentang isi buku yang dibaca siswa alias tanpa tagihan. Fase ini bertujuan

${ }^{24}$ I Made Ngurah Suragangga, Mendidik Lewat Literasi Untuk Pendidikan Berkualitas, JURNAL PENJAMINAN MUTU, Lembaga Penjaminan Mutu Institut Hindu Dharma Negeri Denpasar, Volume 3 (2), 2017, hlm. 159-160.

${ }^{25}$ Tine Silvana Rachmawati, Rohanda, dan Yunus Winoto, Apresiasi Orangtua Siswa Terhadap Program Gerakan Literasi Sekolah (GLS), Prosiding Seminar Nasional Pendidikan FKIP UNTIRTA, UNPAD, 2017, hlm. 369.

${ }^{26}$ Hamdan Husein Btubarra dan Dessy Noor Ariani, Implementasi Program Gerakan Literasi di Sekolah Dasar Negeri Gugus Sungai MIAI Banjarmasin, Banjarmasin: Jurnal Pendidikan Sekolah Dasar (JPSD), UniversitasIslam Kalimantan MAB Banjarmasin, Volume 4 (1), 2018, hlm. 17-18 
membiasakan siswa untuk membaca. Jika siswa yang tidak terbiasa membaca diharuskan membaca lalu ditanya ini-itu tentang isi buku, dikhawatirkan hal demikian membuatnya tertekan. Kondisi tertekan akan membuatnya benci pada kegiatan membaca.

Menurut Billy Antoro ${ }^{27}$ pada tahap pembiasaan, guru sebagai teladan membaca benar-benar diperlukan. Salah satunya adalah dengan cara menunjukkan kegiatan membaca sebagai aktivitas yang menyenangkan dan menghibur. Perlihatkan ekspresi gembira dan bersemangat saat memegang dan membaca buku di hadapan siswa. Cara tersebut akan minat siswa pada kegiatan membaca perlahan akan tumbuh. Sebagai variasi, bisa saja guru bertanya kepada siswa tentang isi buku 2-3 minggu sekali. Beberapa pertanyaan ringan bisa dilontarkan seperti alasan suka membaca, pengetahuan yang diperoleh setelah membaca dan lain sebagainya.

Pentingnya guru dalam program ini, karena guru merupakan unsur pendidikan yang sangat berpengaruh terhadap proses pendidikan. Keberadaan, peranan dan fungsi guru dalam perspektif pandangan islam merupakan keharusan yang tidak dapat dipungkiri. Tidak ada pendidikan tanpa kehadiran guru. Guru merupakan penentu arah dan sistematika pembelajaran mulai dari kurikulum, sarana, bentuk pola sampai kepada usaha bagaimana anak didiknya seharusnya belajar dengan baik dan benar dalam mengakses diri akan pengetahuan dan nilai hidup. ${ }^{28}$

Kegiatan Literasi juga dapat diintegrasikan dalam kegiatan belajar mengajar di sekolah sehingga menjadi bagian tidak terpisahkan dari semua rangkaian kegiatan siswa dan pendidik, baik di dalam maupun di luar kelas Pendidik dan tenaga kependidikan tentu memiliki kewajiban moral sebagai teladan dalam hal berliterasi. Agar lebih masif, program GLS melibatkan partisipasi publik, seperti pegiat literasi, orang tua, tokoh masyarakat, dan profesional. Guna merealisasikan tujuan tersebut, maka SD Negeri Sampangan 02 menunjuk salah satu guru sebagai koordinator program gerakan literasi sekolah. Tujuan dibentuknya koordinator program gerakan literasi adalah untuk memudahkan pelaksanaan kegiatan literasi di sekolah. program-program literasi di sekolah berjalan sesuai harapan. Sama halnya dengan buku panduan gerakan

${ }^{27}$ Billy Antoro, Gerakan Literasi Sekolah: Dari Pucuk Hingga Akar Sebuah Refleksi, Jakarta: Direktorat Jenderal Pendidikan Dasar dan Menengah Kementerian Pendidikan dan Kebudayaan, 2017, hlm. 42

${ }^{28}$ Nur Cholid, Menjadi Guru Profesional, Semarang: CV Presisi Cipta Media, 2015, hlm. 3. 
literasi sekolah, untuk mensukseskan program literasi maka dibentuk sebuah Tim Literasi Sekolah (TLS). Tim ini bertugas memastikan Keanggotaan TLS berasal dari beragam unsur seperti Kepala Sekolah, guru, pustakawan, Komite Sekolah, dan siswa. Kepengurusan TLS disahkan dalam bentuk Surat Keputusan oleh Kepala Sekolah. Tim literasi di SD Negeri Sampangan 02 berasal dari seluruh warga sekolah, kecuali orang tua.

Melalui gerakan literasi sekolah di mana siswa didekatkan dengan beragam bahan bacaan, imajinasi mereka dapat terbangun. "Pergaulan" pikiran dan hati mereka menjadi lebih luas dan terbuka. Mereka mengenal banyak hal di luar jangkauan kehidupan keseharian, bahkan sesuatu yang tidak terpikirkan sebelumnya. Melaui membaca buku fiksi yang ditulis oleh sastrawan dunia, pikiran siswa dapat berkelana ke berbagai belahan benua. Belajar tentang budaya, bahasa, gaya hidup, dan filosofi kehidupan manusia.

Pada lokasi penelitian dapat diketahui bahwa Implementasi program gerakan literasi di SD Negeri Sampangan 02 dapat dianalisis melalui aspek berikut:

Penerapan gerakan literasi pada tahap pembiasaan membaca dikelas IV A dan B SD Negeri Sampangan 02 adalah sebagai berikut:

a. Memberikan waktu 10-15 menit untuk membaca sebelum pembelajaran dimulai, buku yang dibaca adalah buku selain pelajaran.

b. Proses pelaksanaan membaca di dalam atau pun diluar kelas.

c. Peserta didik menulis dan meresum apa yang telah dibaca dari buku bacaan tersebut.

d. Peserta didik menceritakan kembali apa yang telah dibaca di depan kelas secara suka rela.

e. Memberikan apresiasi bagi peserta didik yang bercerita di depan kelas.

f. Guru mencatat buku yang telah dibaca dan dipinjam oleh peserta didik di kartu baca.

Pada tahap penerapan tentunya sudah cukup baik dan kegiatan di dalam tahap pembiasaan ini yaitu 15 menit membaca akan memberikan kebiasaan membaca bagi siswa. Adapun kegiatan membaca setiap hari sebelum jam pelajaran melalui kegiatan membaca buku secara nyaring akan membangun lingkungan fisik sekolah yang kaya literasi. 
Berdasarkan hasil penelitian dapat diketahui bahwa demi mensukseskan program gerakan literasi, SD Negeri Sampangan 02 memberikan fasilitas sarana dan prasarana seperti perpustakaan yang dilengkapi dengan buku mata pelajaran dan buku bacaan, mobil baca keliling, pojok baca, dan tenda baca Sarana dan prasarana gerakan literasi antara lain buku bacaan, buku pengetahuan, perpustakaan, pojok/ sudut baca, mobil baca keliling dari pemerintah Kota Semarang dan tenda baca.

Sarana dan prasarana yang ada di lokasi penelitian telah sesuai dengan panduan gerakan literasi sekolah. Setiap kelas yang ada di SD Negeri Sampangan 02 di berikan fasilitas perpustakaan mini yang isinya puluhan buku bacaan. Buku bacaan tersebut digunakan oleh guru dan peserta didik dalam berliterasi di dalam kelas. Pojok baca ini digunakan peserta didik dalam membaca di dalam kelas.

Strategi program ini adalah dengan guru memberikan tugas yang terkait dengan mata pelajaran. Tugas yang diberikan guru itulah yang membuat peserta didik secara tidak langsung mendatangi mobil baca keliling meskipun harus diberikan tugas terlebih dahulu untuk peserta didik. Metode yang digunakan SD Negeri Sampangan 02 dalam mensukseskan program ini adalah dengan mengadakan lomba pemaparan cerita setiap satu kali dalam satu minggu bagi seluruh peserta didik. Peraih juara dalam lomba cerita tersebut akan dipilih sebagai duta baca di SD Negeri Sampangan 02.

Dipilihnya duta baca di dalam sebuah lembaga merupakan salah satu upaya untuk memotivasi peserta didik dalam membaca. Cara ini, telah dijelaskan dalam buku panduan gerakan literasi sekolah. Bahwasannya guna mensukseskannya gerakan literasi, adalah dengan cara memilih duta baca yang ada di sebuah lembaga. Baik di lembaga sekolah, pendidikan maupun lembaga yang lainnya.

Adanya metode tersebut membuat peserta didik menjadi semangat untuk membaca dan meminjam buku. Baik membaca di dalam kelas, perpustakaan, tenda baca bahkan di mobil baca keliling sekalipun. Setiap peserta didik selesai membaca, maka judul buku yang sudah dibaca tersebut akan ditulis dikartu pintar. Kartu ini bertujuan mencatat buku yang sudah dibaca ataupun buku yang di pinjam. Dari kartu pintar itulah setiap satu bulan sekali akan dievaluasi oleh sekolah untuk menentukan duta bahasa di SD Negeri Sampangan 02 satu bulan kedepan.

Kebijakan sekolah atau dapat berarti rencana sekolah dalam pelaksanaan program gerakan literasi di SD Negeri Sampangan 02. SD Negeri Sampangan 02 memberikan 
kesempatan dengan membuat jadwal yang terkait dengan mobil baca keliling dari dinas pendidikan kota Semarang. Mobil baca keliling ini akan datang setiap hari rabu jam 09.00 WIB pada saat istirahat pertama sampai dengan waktu istirahat habis di setiap satu kali dalam sebulan, dikarenakan kurangnya sumber daya dari dinas pendidikan Kota Semarang. Selain kebijakan diatas, ada beberapa kebijakan yang sekolah berikan dalam mensukseskan program gerakan literasi:

a. Selain membuat jadwal untuk mobil baca keliling, SD Negeri Sampangan 02 memberikan kesempatan bagi peserta didik untuk membaca dan meminjam buku di mobil baca keliling.

b. SD Negeri Sampangan 02 memberikan kesempatan pada perpustakaan sekolah untuk bekerjasama dengan perpustakaan kota guna menambah referensi buku bacaan.

Sasaran untuk program gerakan literasi bukan hanya peserta didik saja tetapi seluruh warga di SD Negeri Sampangan 02 dan Warga sekitar sekolah. Artinya, baik guru, karyawan, dan wali murid termasuk dalam sasaran ini. Bahkan warga yang ada di sekitar SD Negeri Sampangan juga ikut termasuk. Salah satunya para pedagang yang ada di depan SD Negeri Sampangan 02. Hal tersebut sesuai dengan tujuan gerakan literasi dilihat dari pengertian yang diberikan oleh Kemendikbud. Sasaran tersebut bersifat wajib. Artinya, bukan hanya peserta didik saja yang melaksanakan program gerakan literasi. Tetapi, semua warga yang berada di sekitar SD Negeri Sampangan 02 ikut berpartisipasi dalam program tersebut.

Kegiatan evaluasi program dilakukan untuk mengetahui sejauh mana keberhasilan dalam mencapai tujuan pelaksanaan program gerakan literasi. Evaluasi merupakan hal penting dalam kegiatan membaca. Banyaknya jumlah referensi buku bacaan yang dimiliki peserta didik SD Negeri Sampangan 02 akan menjadi penentu peserta didik bisa mendapatkan reward. Berdasarkan hasil penelitian dapat diketahui bahwa evaluasi dalam program gerakan literasi sementara hanya dalam bentuk reward berupa PIN yang dilaksanakan setiap satu bulan sekali. Pemberian PIN dilaksanakan pada pagi hari saat apel pagi di akhir bulan. Apel pagi ini termasuk salah satu agenda dari program gerakan literasi yang dilaksanakan di SD Negeri Sampangan 02. Peserta didik bisa mendapatkan reward jika jumlah referensi buku yang di baca dan dipinjam yang terdapat dalam kartu pintar peminjaman buku yang dimiliki oleh peserta didik. 
Evaluasi program gerakan literasi sekolah di SD Negeri Sampangan 02 dimulai setelah peserta didik membaca buku, setelah membaca peserta didik disuruholeh guru untuk membuat rangkuman buku tersebut. Rangkuman peserta didik itulah yang menjadi bahan acuan kita untuk memberikan penilaian. Penilaian program literasi ini, berupa penilaian rubrik pengamatan. Guru menilai peserta didik dari proses membaca dan memahami buku bacaan tersebut. Dalam proses evaluasi program dilihat dari seberapa banyak buku yang sudah dipinjam dan dibaca oleh peserta didik dilihat dari jumlah buku yang tertulis pada kartu baca yang dimiliki oleh peserta didik masingmasing. Setiap kelas, kartu yang dimiliki oleh peserta didik akan dicek oleh guru kelas nya masing-masing, sehingga guru kelas tersebut melaporkan pada tim program tersebut yang ada di SD Negeri Sampangan 02 .

Dampak dari program gerakan litesi sekolah dapat dilihat adanya pembiasaan membaca yang dilaksanakan setiap hari membuat peserta didik menjadi semakin lebih gemar membaca dengan referensi bacaan yang lebih banyak dan menambah perbendaharaan kata dan menambah wawasan. Dampak tersebut merupakan dampak yang sangat positif bagi siswa meskipun di sisi lain kurangnya jumlah buku dan armada yang disiapkan oleh SD Negeri Sampangan 02 membuat peserta didik menjadi sangat kesulitan untuk mencari buku bacaan yang sesuai dengan minat peserta didik karena masih belum memadai.

Guru dalam mensukseskan kegiatan program memiliki peran yang cukup banyak. Peran guru yang utama dalam gerakan literasi sekolah adalah sebagai fasilitator. Fasilitator disini adalah sebagai orang yang mengarahkan, memberikan contoh yang baik dan mendampingi peserta didik untuk membaca. Selain mengarahkan peserta didik untuk membaca, guru juga dapat ikut membaca, dengan ikut membaca pada dasarya guru sudah mencontohkan kegiatan membaca agar bisa diikuti oleh peserta didik. Peran guru yang lain adalah sebagai pendamping atau mendampingi kegiatan siswa dalam membaca. Pada dasarnya kegiatan pendampingan merupakan kemitraan dan kolaborasi yang sederajat. Ketika seorang guru menjadi pendamping literasi, guru tidak berperan untuk memberikan pelatihan kepada guru lainnya, tetapi berperan sebagai fasilitator. Pelaksanaan pendampingan dilaksanakan secara bersama dalam sinkronisasi, mengarahkan proses dan upaya saling mendukung. Pendampingan bermuatan beragam program literasi dengan topik dan praktik literasi yang efektif dan tepat. Saat 
pendampingan, tidak lagi dibicarakan tentang "pengembangan profesional" karena pengembangan terdengar seperti sesuatu yang hanya dilakukan dalam peningkatan kemampuan personal guru/pendidik/pegiat.

Pendampingan tersebut mendukung refleksi tentang peserta didik, kurikulum, dan pedagogi. Proses pendampingan yang sering terjadi hanya menekankan pada satu aspek pembelajaran dan pengajaran, misalnya, ketika pendamping literasi hanya membahas tentang praktik terbaik atau hanya menyajikan data siswa. Pendamping literasi berhasil ketika rekan guru/pendidik/ pegiat yang didampinginya berhasil membuat keputusan yang dapat meningkatkan pembelajaran literasi. Kegiatan pendampingan literasi dapat dilaksanakan secara langsung bersama dengan para guru/ pendidik/pegiat dalam bentuk pertemuan individu dan kelompok kecil.

\section{SIMPULAN}

Implementasi Program Gerakan Literasi pada Tahap Pembiasaan Membaca Kelas IV di Sekolah Dasar Negeri Sampangan 02 melalui enam tahap. Tahap pertama, memberikan waktu 10-15 menit untuk membaca. Tahap kedua, pelaksanaan di dalam atau pun di luar kelas. Tahap ketiga, meresum apa yang telah dibaca dari buku bacaan tersebut. Tahap keempat, menceritakan kembali apa yang telah dibaca di dedapan kelas secara suka rela. Tahap kelima, memberikan apresiasi bagi peserta didik yang bercerita di depan kelas. Tahap keenam, mencatat buku yang telah dibaca dan dipinjam oleh peserta didik di kartu baca. Pada dasarnya tahapan-tahapan tersebut sudah dilalui secara baik dan berjalan secara lancar.

Dampak positif pelaksanaan Program Gerakan Literasi pada Tahap Pembiasaan Membaca Kelas IV di Sekolah Dasar Negeri Sampangan 02 membuat peserta didik menjadi semakin lebih gemar membaca dengan referensi bacaan yang lebih banyak. Anak-anak yang memiliki kebiasaan membaca, lambat laun akan memiliki ketertarikan terhadap berbagai buku bacaan yang dapat mendukung kegiatan belajar mengajar. Di sisi lain kurangnya jumlah buku yang ada di perpustakaan bila dibandingkan jumlah siswa di Sekolah Dasar Negeri Sampangan 02 menjadi kendala yang dihadapi dalam pelaksanaan progran. Adanya kendala tersebut membuat peserta didik menjadi sangat kesulitan untuk mencari buku bacaan yang sesuai dengan minat, kemauan dan bakat siswa karena masih belum memadai. Hal tersebut menjadi salah satu kendala dalam pelaksanaan program literasi sekolah di Sekolah Dasar Negeri Sampangan 02. 
Peran guru dalam pelaksanaan Program Gerakan Literasi pada Tahap Pembiasaan Membaca Kelas IV di Sekolah Dasar Negeri Sampangan 02 menunjukan bahwa guru kelas IV memiliki peranan yang sangat penting, salah satunya adalah guru sebagai pendamping dan fasilitator. Menjadi pendamping berarti guru mendampingi peserta didik dari awal sampai berakhir dalam proses jalannya kegiatan berliterasi. Guru sebagai pendamping juga bertugas memberikan contoh secara langsung tentang kegiatan membaca yang bisa dilakukan guru, sehingga anak-anak termotivasi secara kuat karena melihat gurunya membaca secara langsung. Kegiatan pendampingan ini bisa dilakukan di dalam kelas, di perpustakaan atau di luar raungan yang dapat memberkan semangat lebih bagi siswa dalam membiasakan membaca. Guru juga berperan sebagai fasilitator. Tugas fasilitor tersebut adalah mengarahkan peserta didik untuk membaca buku. Dalam mengarahkan siswa, tentu guru memiliki tugas utama dalam memberikan arahan buku-buku yang dapat dibaca oleh siswa, terutama yang berkaitan dengan buku bacaan yang ada kaitannya dengan pelajaran, buku-buku yang dapat menambah pengetahuan siswa tentang lingkungan sekitar, perkembangan ilmu pengetahuan dan teknologi. 


\section{DAFTAR PUSTAKA}

Antoro, Billy,Gerakan Literasi Sekolah: Dari Pucuk Hingga Akar Sebuah Refleksi, Jakarta: Direktorat Jendral Pendidikan Dasar dan Menengah Kemendikbud, 2017.

Aprilia, Imelda, Pelaksanaan Program Gerakan Literasi Sekolah Guna Meningkatkan Budaya Membaca Siswa di SD Negeri 2 Limpakuwus (Skripsi), Purwokerto: FKIP PGSD UMP, 2017.

Cholid, Nur, Menjadi Guru Profesional, Semarang: CV Presisi Cipta Media, 2015.

Dalman, Keterampilan Membaca, Jakarta: Rajawali Pers, 2013.

Endaryanta, Eruin, Implementasi Program Gerakan Literasi Sekolah Di Sd Kristen Kalam Kudus dan SD Muhammadiyah Suronatan (Skripsi), Yogyakarta: Fakultas Ilmu Pendidikan UNY, 2017.

Endaryanta, Eruin, Implementasi Program Gerakan Literasi Sekolah Di Sd Kristen Kalam Kudusdan Sd Muhammadiyah Suronatan, JURNAL KEBIJAKAN PENDIDIKAN, Yogyakarta: Fakultas Ilmu Pendidikan UNY, Vol 6, No. 7, 2017

Husein, Hamdan dan Noor Ariani, Dessy, Implementasi Program Gerakan Literasi di Sekolah Dasar Negeri Gugus Sungai MIAI Banjarmasin, Banjarmasin: JPSD, Universitas Islam Kalimantan MAB Banjarmasin, Vol 4, No. 1, 2018

Irdawati, Yunidar, dan Darmawan, Meningkatkan Kemampuan Membaca Permulaan dengan Menggunakan Media Gambar Kelas I di MIN Buol, Jurnal Kreatif Tadulako Online, Tadulako: FKIP Universitas Tadulako, Volume 5 (4).

Iqbal Hasan, M., Pokok-pokok Materi Metodologi Penelitian dan Aplikasinya, Jakarta: Ghalia Indonesia, 2002

Kusumawati, Endah, Peningkatan Keterampilan Membaca Permulaan Melalui Pendekatan Pakem Siswa Kelas I Sd Jomblangan Banguntapan Bantul Tahun Ajaran 2011/2012 (Skripsi), Yogyakarta: Fakultas Ilmu Pendidikan UNY, 2012.

Mardalis, Metode Penelitian, Jakarta: Bumi Aksara, 2002

Nafisah, Aliyatin, 2014, Arti Penting Perpustakaan Bagi Upaya Peningkatan Minat Baca Masyarakat, Jurnal Perpustakaan Libraria, STAIN Kudus, vol 2 No. 2: 70.

Nurhadi, Teknik Membaca, Jakarta: Bumi Aksara, 2016. 
Nur Annisa, Indah., 2017, Implementasi Gerakan Literasi Sekolah (GLS) di Sekolah Dasar (Skripsi), Purwokerto: FKIP Universitas Muhammadiyah Purwokerto, 2017.

Rahim, Farida, Pengajaran Membaca di Sekolah Dasar, Jakarta: Bumi Aksara, 2018.

Septiani, Shinta Tri,. Analisis Literasi Media Pegawai Perpustakaan Proklamator Bung Hatta Bukittinggi (Skripsi), Sumatra Utara: Fakultas Ilmu Budaya Universitas Sumatera Utara, 2014.

Sobirin Ma'as dan Susapti, Peni, Cultural Literacy Building Of Primary School Students As Basic Concept, Salatiga: Mudarrisa Jurnal Kajian Pendidikan Islam, IAIN Salatiga, Vol. 10, No. 2, 2018

Suharsimi Arikunto, Prosedur Penelitian Kualitatif, Jakarta: Rineka Cipta, 2010

Suyono, Titik Harsiati, dan Ika Sari Wulandari. 2017. Implementasi Gerakan Literasi Sekolah Pada Pembelajaran Tematik Di Sekolah Dasar, JURNAL SEKOLAH DASAR KAJIAN TEORI DAN PRAKTEK PENDIDIKAN, Malang: Fakultas Sastra Universitas Negeri Malang, No. 2: 117.

Teguh, Mulyo., Aktualisasi Kurikulum 2013 Di Sekolah Dasar Melalui Gerakan Literasi Sekolah Untuk Menyiapkan Generasi Unggul Dan Berbudi Pekerti, Pengawas pada Dinas Pendidikan Kabupaten Pati, Prosiding Seminar Nasional, 2017.

Tine Silvana, Rohanda, dan Yunus Winoto, Apresiasi Orangtua Siswa Terhadap Program Gerakan Literasi Sekolah (GLS), Prosiding Seminar Nasional Pendidikan FKIP UNTIRTA, UNPAD, 2017.

T. p, Panduan Gerakan Literasi Sekolah Dasar, Jakarta: Bagian Perencanaan dan Penganggaran Sekretariat Direktorat Jenderal Pendidikan Dasar dan Menengah, 2016.

T. p, Panduan Gerakan Literasi Nasional, Jakarta Timur: Kementerian Pendidikan dan Kebudayaan Jakarta, 2017.

T. p, Panduan Gerakan Literasi Sekolah di SD, Jakarta: Direkotorat Pembinaan Sekolah Dasar Direktorat Jendral Pendidikan Dasar dan Menengah, 2016.

T.p, Pedoman Pelaksanaan Gerakan Nasional Literasi Bangsa, Jakarta: Bidang Pembelajara Pusat Pembinaan dan Pembinaan Bahasa Kementerian Pendidikan dan Kebudayaan, 2016.

Wandasari,Yulisa., 2017, Implementasi Gerakan Literasi Sekolah (GLS) Sebagai Pembentuk Pendidikan Berkarakter, Jurnal Manajemen, Kepemimpinan, Dan Supervisi Pendidikan (JMKSP), Sumatra Selatan: SMKN 1 Tanah Abang, Vol 1 No. 1: 329. 
Wijaya Antasari, Indah. 2017. Implementasi Gerakan Literasi Sekolah Tahap Pembiasaan di MI Muhammadiyah Gandatapa Sumbang Banyumas. Jurnal LIBRIA. Purwokerto: IAIN Purwokerto. Vol. 9 No. 1: 17. 